\title{
Submicron Particle Paclitaxel Sterile Suspension
}

National Cancer Institute

\section{Source}

National Cancer Institute. Submicron Particle Paclitaxel Sterile Suspension. NCI

Thesaurus. Code C162773.

A suspension composed of uncoated, stable, submicron particles of the water-insoluble taxane paclitaxel, with potential antineoplastic activity. Upon intra-tumoral administration of the submicron particle paclitaxel sterile suspension, paclitaxel binds to tubulin and inhibits the disassembly of microtubules, which leads to the inhibition of cell division, thereby halting the proliferation of rapidly-dividing tumor cells. The submicron particle paclitaxel is produced through a specific proprietary method of submicron particle production without the need for coating agents or carriers and allows for prolonged retention and sustained release at the tumor site. 